\title{
Laparoscopic Cholecystectomy in a Patient with Empty Sella Turcica
}

\author{
Jyoti Pathanial, Anshit Abhi Pathania ${ }^{2 *}$, Vishal Thakur ${ }^{3}$ \\ ${ }^{1}$ Professor, Anaesthesia, ${ }^{2}$ Senior Resident, Anaesthesia, ${ }^{3}$ Senior Resident, Surgery, Indira Gandhi \\ Medical College, Shimla, India
}

\begin{abstract}
Empty sella turcica is a condition in which the pituitary gland is absent completely or partially from the sella turcica or pituitary fossa. The patient may be asymptomatic with empty sella turcica as an incidental finding, or may have symptoms of pituitary hormones deficiency. Perioperative management of these patients depends on the symptoms and signs of hormonal deficiencies and the hormonal replacement treatment.
\end{abstract}

Key words: empty Sella Turcica, Sheehan's Syndrome, hypopituitarism, laparoscopic surgery, steroid replacement

\section{Introduction}

The Sella turcica is a depression in the sphenoid bone where the pituitary gland is situated. Empty Sella Syndrome (ESS) is a condition where the pituitary gland is partially or totally absent from the pituitary fossa. Symptomatic ESS is a rare entity, and it is commonly found as an incidental finding during brain studies. ESS can be primary or secondary. In Primary ESS there is defective development of the diaphragma sellae, which results in arachnoid herniation to the pituitary fossa due to increased intra cranial pressure. ${ }^{1,2}$ Secondary ESS is due to infarction or atrophy of pituitary gland, due to tumor surgery, trauma or radiation and is usually found in obese and middle-aged women. ${ }^{3}$ In our case, the patient was posted for laparoscopic cholecystectomy and was evaluated due to unusual findings during preoperative assessment.

\section{Case History}

A 53-year-old female attended the PreAnaesthetic Clinic (PAC) for an elective

*Correspondence: Anshit Abhi Pathania E mail: apathania26@gmail.com

iD https://orcid.org/0000-0001-8296-9525 Received: $18 / 06 / 2020$

Accepted: $20 / 08 / 2020$

DOI: http:/doi.org/10.4038/slja.v29i1.8619 laparoscopic cholecystectomy. The patient was a known case of hypothyroidism for the last 10 years and was taking thyroxine $50 \mathrm{mcg}$ once daily. She had no other medical problems. On inquiring about her menstrual history, she was found to be menopausal since her last child birth, i.e., since the age of 30 years. She had an unassisted home deliveries and lactation failure and amenorrhea followed both. According to the patient, she started losing her axillary and pubic hair and had weight loss after that, for which she visited many clinicians and was diagnosed as hypothyroid.

On examination, the patient was lean (weight 60 $\mathrm{kg}$ ), well oriented, with no abnormal clinical signs. Cardiovascular and respiratory parameters were within normal limits. The hematological investigations showed no abnormality. (Table1) The patient was then referred to an endocrinologist.

The patient was again reviewed in PAC after the endocrine workup in which MRI impression showed marked atrophy of anterior pituitary with completely empty sella. (Image1, 2) Thyroid function tests were within the normal limits. The serum prolactin and 8 am cortisol levels were reduced (Table 2). The patient was diagnosed as Sheehan's syndrome (SS) due to her obstetric history. She was started on tablets hydrocortisone $5 \mathrm{mg}$ morning, $2.5 \mathrm{mg} 2 \mathrm{pm}$ and $6 \mathrm{pm}$ along with tab calcium $500 \mathrm{mg} 6$ hourly and thyroxine continued. 
Table 1

Routine Investigations during PAC

\begin{tabular}{|l|l|}
\hline Fating blood sugar & $95 \mathrm{mg} / \mathrm{dL}$ \\
\hline Blood Urea Nitrogen & $9 \mathrm{mg} / \mathrm{dL}$ \\
\hline Creatinine & $0.9 \mathrm{mg} / \mathrm{dL}$ \\
\hline S. $\mathrm{Na}^{+}$ & $142 \mathrm{mmol} / \mathrm{L}$ \\
\hline S. $\mathrm{K}^{+}$ & $3.80 \mathrm{mmol} / \mathrm{L}$ \\
\hline S. Cl & $105 \mathrm{mmol} / \mathrm{L}$ \\
\hline S. Bilirubin (total) & $0.44 \mathrm{mg} / \mathrm{dL}$ \\
\hline SGPT/SGOT & $25 / 38 \mathrm{U} / \mathrm{L}$ \\
\hline ALP & $195 \mathrm{U} / \mathrm{L}$ \\
\hline Serum total protein & $6.9 \mathrm{~g} / \mathrm{dL}$ \\
\hline
\end{tabular}

Table 2

Investigations after endocrinology workup

\begin{tabular}{|c|c|c|}
\hline Investigations & $\begin{array}{l}\text { Patient } \\
\text { Value }\end{array}$ & Normal Range \\
\hline T3 & 126.26 & $58-159 \mathrm{ng} / \mathrm{dl}$ \\
\hline T4 & 6.74 & $4.87-11.71 \mu \mathrm{g} / \mathrm{dl}$ \\
\hline $\begin{array}{l}\text { TSH } \\
3^{\text {rd }} \text { generation }\end{array}$ & 0.846 & $0.35-4.94 \mu \mathrm{lU} / \mathrm{ml}$ \\
\hline $\begin{array}{l}\text { S. Cortisol } \\
8: 00 \mathrm{am}\end{array}$ & 3.83 & $5-23 \mu \mathrm{g} / \mathrm{dl}$ \\
\hline $\begin{array}{l}\text { FSH } \\
\text { (follicular } \\
\text { stimulating } \\
\text { hormone) }\end{array}$ & 3.85 & $\begin{array}{l}\text { Follicular phase: } \\
\text { 3.03-8.08 mlU/ml } \\
\text { Mid Cycle: } 2.55-16.69 \\
\text { Luteal: } 1.38-5.47 \\
\text { Post -menopausal: } \\
\text { 26.73- } 133.41\end{array}$ \\
\hline $\begin{array}{l}\text { LH } \\
\text { (luteinizing } \\
\text { hormone) }\end{array}$ & 0.94 & $\begin{array}{l}\text { Follicular phase: } \\
1.80-11.7 \mathrm{mlU} / \mathrm{ml} \\
\text { Mid cycle: } 7.59-89.08 \\
\text { Luteal: } 0.5-14.00 \\
\text { Post -menopausal: } \\
5.16-61.99\end{array}$ \\
\hline Prolactin & 4.36 & $5.18-26.53 \mathrm{ng} / \mathrm{ml}$ \\
\hline Estradiol & 16.23 & $\begin{array}{l}\text { Follicular: } \\
\text { 12.4-233 pg/ml } \\
\text { Ovulation: } 41.0-398 \\
\text { Luteal: } 22.3-341 \\
\text { Post menopausal <5 }\end{array}$ \\
\hline Serum calcium & 10.8 & $8.6-10.3 \mathrm{mg} / \mathrm{dl}$ \\
\hline $\begin{array}{l}\text { Serum } \\
\text { phosphorus }\end{array}$ & 4.6 & $2.5-4.9 \mathrm{mg} / \mathrm{dl}$ \\
\hline
\end{tabular}

Elective laparoscopic cholecystectomy was planned for this patient with SS who was diagnosed after more than 20 years of disease onset. The case was discussed with the consulting endocrinologist for perioperative management.

On the day of surgery, intravenous access with
$18 \mathrm{G}$ cannula was secured in the ward and iv fluid started at 6:00 am at $100 \mathrm{ml} /$ hour with Ringer Lactate. The patient was taken to OT at 10:00 am. ASA standard monitoring applied with NIBP $=116 / 12 \mathrm{mmHg}$, 5 lead ECG with HR $=70 / \mathrm{min}$ and pulse oximetry with $\mathrm{SPO}_{2}=96 \%$ on room air.

General anaesthesia (GA) with cuffed endotracheal intubation was planned. Hydrocortisone $100 \mathrm{mg}$ iv was given before the induction of anaesthesia. GA was induced with Fentanyl $100 \mathrm{mcg}$ and Propofol was given in incremental doses muscle relaxation achieved with atracurium $30 \mathrm{mg}$. Anaesthesia was maintained with $0_{2} 33 \%+\mathrm{N}_{2} \mathrm{O} 66 \%+$ Isoflurane $0.8-1 \%$.

Hydrocortisone infusion was started at $6 \mathrm{mg} / \mathrm{hour}$ after induction and maintained. Intraoperative hemodynamics were well maintained and no active intervention was required. Reversal of

\section{Image 1}

Coronal T2 image of sella shows empty sella turcica.

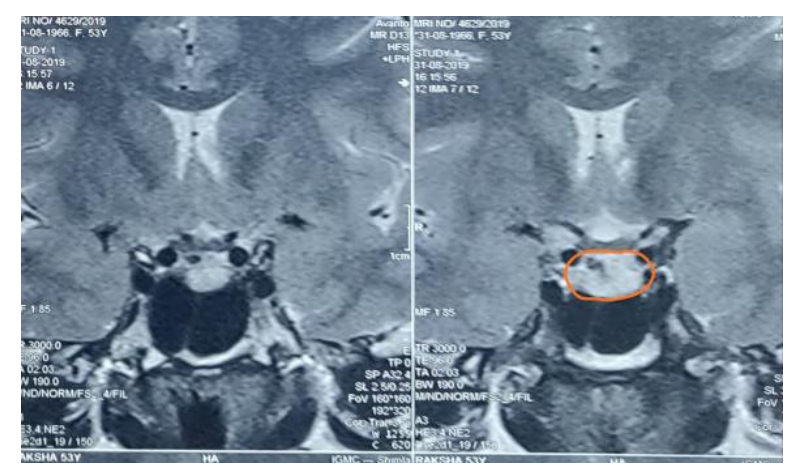

\section{Image 2}

T1 non-fat saturated sagittal image of sella shows empty sella with very small T1 posterior pituitary bright spot labeled in image: 1) optic chiasma 2) pituitary stalk 3) T1 bright spot of pituitary

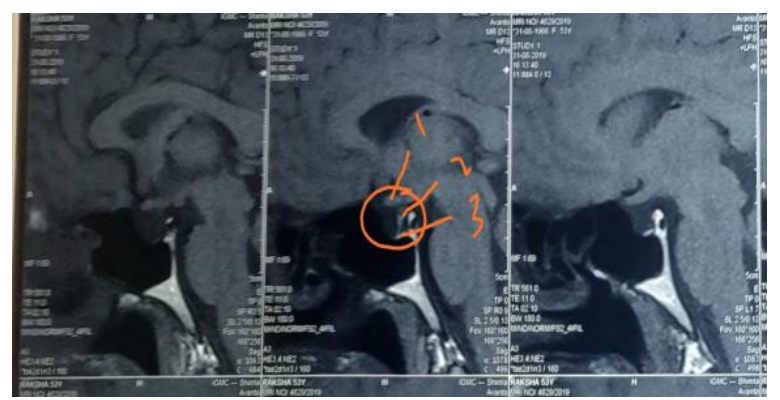


anaesthesia and recovery was uneventful. The hydrocortisone infusion was continued at 6 $\mathrm{mg} /$ hour for first 24 hours postoperatively (postoperative day 0 POD0); on POD1 hydrocortisone $50 \mathrm{mg}$ iv 8 hourly and then $25 \mathrm{mg}$ 8 hourly. The patient was then shifted to oral hydrocortisone as per the preoperative dose. The hemodynamics were stable and patient remained comfortable during the postoperative period.

\section{Discussion}

Sheehan's Syndrome (SS) occurs as a result of ischemic pituitary necrosis due to severe postpartum hemorrhage. It is one of the most common causes of hypopituitarism and secondary ESS in females of underdeveloped or developing countries. ${ }^{4} \quad$ Characteristic manifestations include failure to lactate or to resume menses, genital and axillary hair loss, asthenia and weakness, fine wrinkles around the eyes and lips, signs of premature aging, dry skin, hypopigmentation and other evidence of hypopituitarism. ${ }^{4}$ It may sometimes present with acute circulatory collapse, severe hyponatremia, diabetes insipidus, hypoglycemia, congestive cardiac failure or psychosis. ${ }^{5,6} 70 \%$ of the patients with SS has empty sella image on MRI and $30 \%$ has partial empty sella. ${ }^{7}$

A patient with SS diagnosed after more than 20 years of disease onset poses a great challenge for the anaesthesia team. Our patient had deficiency of anterior pituitary hormones, but there were no signs of SIADH or posterior pituitary hormone deficiency. The anesthetic complications in a patient with SS include hypotension not responding to the standard treatment, decrease in core body temperature, decreased anesthetic drug requirement due to reduced metabolism, higher incidence of postoperative gastrointestinal and neuropsychiatric complications, electrolyte and coagulation disturbances, delayed emergence from anesthesia, perioperative stress management, and steroid management. Also, the main concern was intraoperative and postoperative Addisonian crisis which may get precipitated by surgical stress and related complications. $^{8}$ Therefore, a bolus dose of hydrocortisone was given before induction followed by an infusion which was continued for 24 hours post operatively followed by the maintenance doses.

In a case report of anaesthetic management of a parturient with SS undergoing caesarean section, who underwent a subarachnoid block, hydrocortisone was given as an iv infusion until the patient was able to take oral steroids. In another case reported, a patient with hypopituitarism undergoing epigastric hernioplasty, the patient experienced hypotension requiring inotropes, had delayed awakening from general anesthesia and required postoperative mechanical ventilation. ${ }^{10}$

We kept inotropes ready for use in the OT, and also ICU bed with ventilator support was booked. Fortunately, our patient did not require inotropic support and the recovery was uneventful.

After a substantial literature review, we could not find any consensus or guidelines for the perioperative management of patients with SS or ESS. Even the anaesthestic management of such cases is sparse. The successful management is a team effort between endocrinologist, surgeon and anaesthetist, concentrating on the hormonal profile of the patient, management of steroid doses and anticipation of critical events.

\section{References}

1. Saindane AM, Lim PP, Aiken A, Chen Z, Hudgins PA. Factors determining the clinical significance of an "empty" sella turcica. AJR Am J Roentgenol. 2013; 200: 1125-31.

https://doi.org/10.2214/ajr.12.9013

PMID: 23617499

2. Naing S, Frohman LA. The empty sella. Pediatr Endocrinol Rev. 2007; 4:335-42.

https://doi.org/10.1097/01.cne.0000270616.23240. $\underline{\mathrm{Od}}$

PMID: 17643081

3. Melmed S, Kleinberg D, Ho Ken. Pitutary physiology and diagnostic evaluation. In: Kronenberg HM, Melmed S, Polonsky KS, Larsen $\mathrm{PR}$, editors. Williams textbook of endocrinology, Chap 8. 12th ed. Philadelphia: Elsevier; 2011. https://doi.org/10.1016/b978-1-4377-03245.00008-0

4. C. Shivaprasad. Sheehan's syndrome: Newer advances. Indian J Endocrinol Metab. 2011; 15 (3): S203-7.

https://doi.org/10.4103/2230-8210.84869 PMID: 22029025

5. Wang SY, Hsu SR, Su SL, Tu ST. Sheehan's syndrome presenting with early postpartum congestive heart failure. J Chin Med Assoc. 2005; 68: $386-91$.

https://doi.org/10.1016/s1726-4901(09)70181-9 PMID: 16138719 
6. Weston G, Chaves N, Bowditch J. Sheehan's syndrome presenting post-partum with diabetes insipidus. Aust NZJ Obstet Gynaecol. 2005; 45: 249-50.

https://doi.org/10.1111/j.1479-828x.2005.00367.x PMID: 15904455

7. Kaplun J, Fratila C, Ferenczi A, Yang WC, Lantos G, Fleckman AM, et al. Sequential pituitary MR imaging in Sheehan syndrome: Report of 2 cases. AJNR Am J Neuroradiol. 2008; 29: 941-3. https://doi.org/10.3174/ajnr.a1016 PMID: 18296547

8. Koo D J, Jackman D, Chaudry IH, Wang P. Adrenal insufficiency during the late stage of polymicrobial s eps is. Crit. Care Med. 2001 Mar; 29 (3): 618-22.

https://doi.org/10.1097/00003246-200103000$\underline{00026}$

PMID: 11373430
9. G Arora, N Sahni. Anesthetic management of a patient with Sheehan's syndrome and twin pregnancy while undergoing a cesarean section. $J$ Postgrad Med. $2020 \mathrm{~J} ; 66$ (1): 51-3. https://doi.org/10.4103/jpgm.jpgm_473 19 PMID: 31929313

10. Choudhuri R, Sandeep KK, Adhikari D, Sinha S. Anaesthetic management of a dwarf with hypopituitarism presenting for epigastric hernioplasty: A case report. $J$ Metabolic Synd. 2014; 3: 154.

https://doi.org/10.4172/2167-0943.1000154 